\title{
27. CENOZOIC EVOLUTION OF THE NEW JERSEY COASTAL PLAIN: CHANGES IN SEA LEVEL, TECTONICS, AND SEDIMENT SUPPLY ${ }^{1}$
}

\author{
Kenneth G. Miller,, ${ }^{2,3}$ James V. Browning, ${ }^{2}$ Stephen F. Pekar, ${ }^{2}$ Peter J. Sugarman ${ }^{2,4}$
}

\begin{abstract}
The New Jersey Coastal Plain Drilling Project continuously cored three boreholes at Island Beach, Atlantic City, and Cape May, New Jersey. Sequence boundaries in the cores are expressed as physical surfaces, lithofacies breaks, and paraconformities (hiatuses) recognized using biostratigraphy and Sr-isotopic stratigraphy. By drilling along dip and strike profiles, we assembled a mosaic of 29 Paleocene to Miocene sequences and dated them using integrated magnetostratigraphy, biostratigraphy, and isotopic stratigraphy.

Correlation between major late middle Eocene to middle Miocene $(42-10 \mathrm{Ma})$ onshore sequence boundaries and $\delta^{18} \mathrm{O}$ increases (inferred glacioeustatic lowerings) indicates that eustasy exerts a primary control on sequence boundaries. Onshore sequence boundaries also correlate with Miocene unconformities on the New Jersey shelf and slope, Oligocene to middle Miocene unconformities in Florida, early Oligocene unconformities in Alabama, and the sequence boundaries of Exxon. Such regional and interregional correlations support a eustatic control. However, early middle Eocene correlations between sequence boundaries and $\delta^{18} \mathrm{O}$ increases are equivocal, and it is not clear that glacioeustatic changes occurred at this time. In contrast, early Eocene sequence boundaries do not correlate with $\delta^{18} \mathrm{O}$ change, and we infer ice-free conditions at this time; nevertheless early Eocene sequence boundaries do correlate with those of Exxon, indicating that they may record global sea-level events. However, there is no known mechanism for explaining such large, rapid early Eocene eustatic variations other than glacioeustasy. Paleocene sequence boundaries apparently do not match the Exxon sequence boundaries, and further study of New Jersey Paleocene sequences is warranted.

Regional and local tectonics resulted in differential preservation of sequences in the Mid-Atlantic Coastal Plain. For example, lower Miocene marine sequences are well represented in New Jersey, but are less complete in Maryland, whereas the converse is true for upper Miocene marine sequences. The tectonic mechanism responsible for this distributional pattern has not been established. In general, Miocene downdip sections in New Jersey are stratigraphically more complete than updip sections, reflecting a hinged margin with increased subsidence downdip. In contrast, Oligocene sequences have a patchy distribution: lower Oligocene sequences are better preserved updip at Island Beach, and middle Oligocene sequences are better preserved at Atlantic City than they are downdip at Cape May. These differences result from differential subsidence on the order of tens of meters and probably reflect migration of sediment supply and depocenters. Eocene sequences are widely distributed throughout the New Jersey Coastal Plain, reflecting high sea level and deposition in deep (>100 m) water.

New Jersey Coastal Plain sequences were also influenced by sediment supply and climate. Low siliciclastic and high pelagic input during the early to middle Eocene resulted in carbonate silty clay deposition in association with warm regional and global climates. By the late Eocene, climatic cooling resulted in dominance by uniform siliciclastic clays onshore, although pelagic carbonate deposition dominated offshore. The entire margin was sediment starved in the early Oligocene. Siliciclastic input increased in the late Oligocene and again in the Miocene with a shift to deltaic sedimentation, perhaps related to hinterland tectonics. Thus, the New Jersey Margin progressively evolved from an early to middle Eocene carbonate ramp, to a late Eocene mixed carbonate-siliciclastic ramp, to a sediment-starved region in the early Oligocene, to a ?late Oligocene to middle Miocene siliciclastic progradational margin with high sedimentation rates. We also note the progressive shallowing onshore from outer neritic $(\sim 185 \mathrm{~m})$ environments in the early Eocene, to generally inner to middle neritic environments in the Oligocene, to inner neritic prodelta, marginal marine, and fluvial environments in the Miocene.
\end{abstract}

\section{INTRODUCTION}

The New Jersey Coastal Plain Drilling Project (Ocean Drilling Program [ODP] Leg 150X) drilled boreholes at Island Beach (total depth $1223 \mathrm{ft}$ [372.7 m]; April-May, 1993; Miller et al., 1994a), Atlantic City (total depth $1452 \mathrm{ft}$ [442.6 m]; June-August, 1993; Miller et al., 1994b), and Cape May (total depth $1500 \mathrm{ft}$ [457.2 m]; MarchApril, 1994; Miller, et al., 1996a). Onshore drilling is part of the New Jersey Sea-level Transect. The Transect was designed to sample slope, shelf, and coastal plain sediments, primarily along a dip profile that is anchored on the seaward side by Deep Sea Drilling Project

'Miller, K.G., and Snyder, S.W. (Eds.), 1997. Proc. ODP, Sci. Results, 150X: College Station, TX (Ocean Drilling Program).

${ }^{2}$ Department of Geological Sciences, Rutgers University, Piscataway, NJ 08855, U.S.A. kgm@ rci.rutgers.edu

U.S.A.

${ }^{4}$ New Jersey Geological Survey, CN 427, Trenton, NJ 08625, U.S.A drilling on the lower slope and rise (Legs 93 and 95; Poag, Watts, et al., 1987; van Hinte, Wise, et al., 1987). The Transect includes drilling offshore by ODP Leg 150 slope drilling (Mountain, Miller, Blum, et al., 1994), Leg 174A shelf drilling (Summer 1997), and future shelf drilling (Fig. 1; see Miller and Mountain [1994] for discussion and history of the Transect). The primary goals of the New Jersey Sea-level Transect are (1) to date major "Icehouse" (OligoceneHolocene) sequences, a time of known glacioeustatic change (Miller et al., 1991), (2) to compare the timing of these sequences with ages predicted from the oxygen isotopic proxy of glacioeustasy, (3) to estimate the amplitudes and rates of the sea-level change, and (4) to evaluate sequence stratigraphic models (e.g., the systems tracts of Posamentier et al., 1988).

One of the primary objectives of onshore drilling was to sample the updip equivalents of sequences (unconformity bounded units) found offshore (see Miller, Chapter 1, this volume, for summary). Onshore drilling also provided another setting in which to date sequences sampled on the slope by Leg 150 (Mountain, Miller, Blum, et al., 1994) and to delineate facies relationships in a region sensitive 


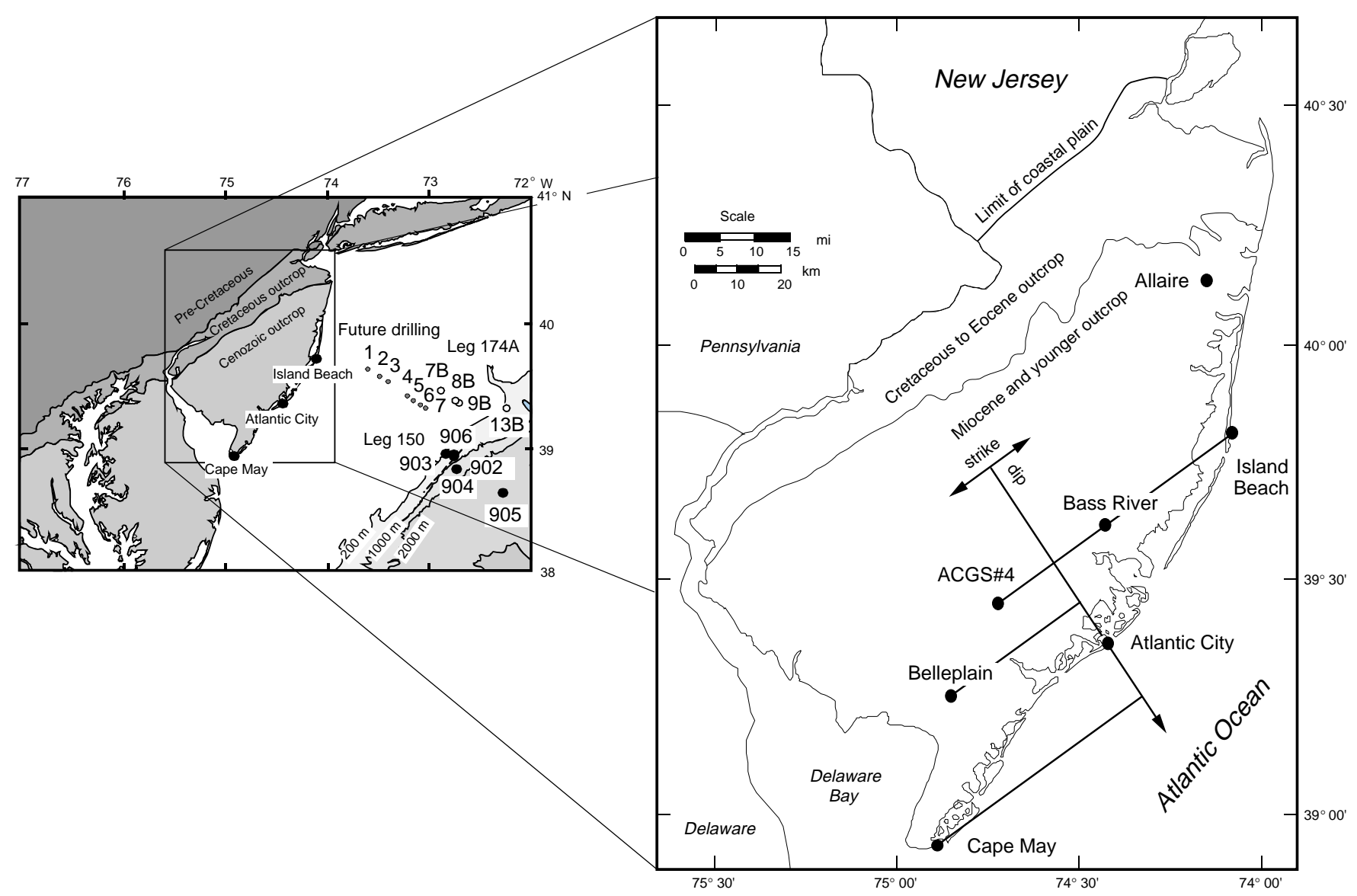

Figure 1. Location map of the mid-Atlantic region, showing relationship between slope sites drilled as a part of ODP Leg 150, coastal plain sites drilled as a part of Leg 150X, and proposed future drilling. Inset map shows locations of major boreholes on the New Jersey Coastal Plain that are discussed in the text. Contact in New Jersey between Cretaceous to Eocene outcrop and Miocene and younger outcrop from Enright (1969). Outcrop belts on inset are shown only for New Jersey. Generalized Cenozoic strike and dip direction is shown; the boreholes are projected onto a dip profile through Atlantic City, illustrating both the strike and dip components sampled by our boreholes.

to sea-level change, allowing more comprehensive evaluation of sequence facies models (Posamentier et al., 1988). Onshore drilling also addressed three other problems. First, it provided the only detailed sampling of Paleocene-Eocene sequences, which accumulated during an interval when the causes of global sea-level change are controversial (see Browning et al. [Chapter 17, this volume] for discussion). Second, it provided an along-strike sampling of sequences (vs. the more dip-parallel sampling of shelf and slope drilling) that provides constraints on differences in tectonic subsidence in this region (Fig. 1). Third, it provided a setting more proximal to sediment sources in which changes in sediment supply and provenance could be more clearly evaluated.

Debate has centered on the role of tectonics vs. eustasy as the dominant process in shaping the stratigraphic record of the U.S. MidAtlantic passive continental margin. Owens and co-authors (Owens, 1970, 1983; Owens and Gohn, 1985; Owens et al., 1968, 1970, 1977) suggested that the U.S. Mid-Atlantic Coastal Plain basins and arches are caused by warping at different places at different times (see fig. 1 in Owens et al., Chapter 2, this volume for map of basins). Their work emphasized stratigraphically mappable differences within and between basins on this margin. There is evidence that basement faulting is also important in the mid-Atlantic region (Benson, 1990), and such faulting of crustal blocks has been invoked to explain the basins and arches on this margin (Brown et al., 1972).

Despite evidence of regional and local tectonics, it is clear that eustasy has shaped the Cretaceous to Quaternary deposition on this margin (e.g., Olsson, 1991; Sugarman et al., 1993), and that the New Jersey Margin is a suitable location to evaluate sea-level change. In addition to the effects of sea level and tectonics, mapping of strata both onshore and offshore demonstrates that changes in sediment supply and provenance caused by hinterland tectonics have affected the distribution and thickness of sediments (Poag and Sevon, 1989; Owens et al., 1995a, 1995b). However, only by sampling at numerous locations, both along dip and along strike profiles, can the complex interplay of changes in eustasy, tectonics, and sediment supply be unraveled.

Miller (Chapter 1, this volume) provides an overview of the goals, strategies, and material recovered by New Jersey Coastal Plain Drilling Project. Preliminary lithostratigraphic, biostratigraphic, Sr-isotopic, and sequence stratigraphic data were published in the site reports (Miller et al., 1994a, 1994b; Miller, et al., 1996a). Subsequent studies have developed a sequence stratigraphic framework for different parts of the Cenozoic by integrating chronologic, lithostratigraphic, well-log, core-log, benthic foraminiferal biofacies, and isotopic studies. These studies include evaluation of unconformities and flooding surfaces, delineating systems tract variations within sequences, and estimating water-depth variations within sequences. Miocene sequence stratigraphic frameworks are presented by Sugarman et al. (Chapter 12, this volume), Miller et al. (Chapter 14, this volume), Miller and Sugarman (1995), and Sugarman and Miller (1997). The Oligocene framework is developed by Pekar and Miller (1996) and Pekar et al. (Chapter 15, this volume). Browning et al. (Chapter 17, 
this volume) and Browning et al. (Chapter 18, this volume) provide an integrated framework for the Eocene of the New Jersey Coastal Plain including the Leg 150X boreholes, the Allaire borehole, and the ACGS\#4 borehole. Liu et al. (Chapter 19, this volume) evaluate the Paleocene sequences at Island Beach.

This paper synthesizes results of these sequence stratigraphic studies and addresses Cenozoic changes in sea level, tectonics, and sediment supply. We provide an overview of the relationship between New Jersey Coastal Plain sequences and two proxies of global sea-level change: the benthic foraminiferal $\delta^{18} \mathrm{O}$ and Haq et al. (1987) records. Comparison of updip and downdip locations reveals minor differences in tectonic subsidence history of the New Jersey Coastal Plain during the Cenozoic. Changes in sediment composition and accumulation rate in the New Jersey Coastal Plain are related to regional/global climate changes and variations in hinterland tectonics. We conclude that although eustasy is the primary control on the formation of sequences, the preservation and architecture of sequences are influenced by tectonics and sediment supply.

\section{NEW JERSEY COASTAL PLAIN SEQUENCES}

We compare (Fig. 2) Cenozoic sequences in the three Leg 150X boreholes with continuously cored updip sections at Allaire State Park (Fig. 1) and the ACGS\#4 borehole (Fig. 1; Owens et al., 1988; Poore and Bybell, 1988; Miller et al., 1990; Sugarman et al., 1993; Browning et al., Chapter 17, this volume). Although not all sequences are represented in any one borehole, by sampling at numerous locations we have assembled a composite of 29 Paleocene to middle Miocene sequences (Fig. 2). Most sequences (20 of 29) are found in more than one borehole examined here (Fig. 2).

Sequences are named alphanumerically from older to younger, with pa1-3 representing three Paleocene sequences, E1-11 representing 11 Eocene sequences, O1-6 representing six Oligocene sequences, and $\mathrm{Kw} 0$ to $\mathrm{Kw}$-Cohansey representing nine lower to middle Miocene sequences. Upper Miocene strata are difficult to date because they are marginal-marine to estuarine, although dinocysts allow identification and correlation of four upper Miocene sequences (Ch36; de Verteuil, Chapter 11, this volume) within the estuarine to nearshore deposits at Cape May. No definite Pliocene strata were identified in the boreholes (tentatively recognized ?Pliocene strata at Cape May [Miller, et al., 1996a] are now identified as uppermost middle and upper Miocene based on dinocysts; de Verteuil, Chapter 11, this volume). Pleistocene sections in these boreholes are also difficult to date, with only four radiocarbon dates (Miller et al., 1994a; Miller, et al., 1996a) and one interval of amino acid dates available (Wehmiller, Chapter 26, this volume). Because of problems in dating these upper Neogene sediments, we restrict our comparisons to Paleocene to middle Miocene strata.

Paleocene sequences have been recovered only in one continuously cored site (Island Beach). Although these Paleocene sequences are consistent with sequences reported elsewhere in the New Jersey Coastal Plain from outcrops and discontinuously sampled boreholes (Olsson and Wise, 1987b), further studies are needed to determine their age and regional distribution.

Lower to middle Eocene sequences are dated by integrated magnetobiostratigraphy, with a resolution generally better than 0.5 m.y. (Browning et al., Chapter 17, this volume). The lower to middle Eocene sequences shown here (Fig. 2) agree with previous studies of New Jersey Coastal Plain Eocene sequences (Olsson and Wise, 1987b; Miller et al. 1990), but are more reliably tied to the Geomagnetic Polarity Time Scale. Previous studies had more limited chronostratigraphic resolution because of discontinuous sampling of boreholes (Olsson and Wise, 1987b) and incomplete lower Eocene recovery (Miller et al., 1990).

Upper Eocene strata were first identified in the Cape May region (Brown et al., 1972; Poag, 1985), although the only well-recovered and dated upper Eocene section prior to Leg 150X was obtained at the ACGS\#4 borehole (Owens et al., 1988; Poore and Bybell, 1988; Miller et al., 1990; Christensen et al., 1995). Browning et al. (Chapter 18, this volume) recognize two distinct upper Eocene sequences (E10-11), above a stratigraphically mixed interval (Sequence E9) that may be age equivalent to the Chesapeake Bay impact event (Poag et al., 1994; Poag and Aubry, 1995). The ages of the upper Eocene sequences E10 and E11 (Fig. 2) are only moderately well constrained ( \pm 0.5 m.y.), whereas the duration of Sequence E9 cannot be estimated.

Prior to Leg 150X, Oligocene sequences were known only from discontinuously cored boreholes (Olsson et al., 1980), rotary wells (Poag, 1985), and a poorly recovered section at the ACGS\#4 borehole (Owens et al., 1988). Although Oligocene sequences recovered by Leg $150 \mathrm{X}$ are relatively well dated by integrating Sr-isotopic stratigraphy with planktonic foraminiferal and nannofossil biostratigraphy, there are still uncertainties in their identification and age. For example, although $\mathrm{O} 4, \mathrm{O} 5$, and $\mathrm{O} 6$ appear to be distinct sequences separated by disconformities, the hiatuses associated with the $\mathrm{O} 5$ and O6 sequence boundaries are not discernible within the 0.5- to 1.0-m.y resolution afforded by Sr-isotope stratigraphy and biostratigraphy. Therefore, it is possible to interpret Sequences O4-O6 as three parasequences within one thick sequence (Pekar et al., Chapter 15, this volume). One lowermost Oligocene sequence (ML) has been reported only from the ACGS\#4 borehole, and it is not certain whether this is a sequence distinct from $\mathrm{O} 1$. Sequence $\mathrm{O} 4$ has been reported only from one site (Cape May), and its regional and inter-regional significance requires verification.

Applying Sr-isotopic stratigraphy and diatom biostratigraphy to the continuously cored sections at ACGS\#4 and Belleplain boreholes (Fig. 1), Sugarman et al. (1993) recognized, dated, and mapped three major lower to middle Miocene sequences (Kw1, Kw2, and Kw3, equivalent to East Coast Diatom Zones 1, 2, and 6, respectively). Subsequent studies conducted on Leg 150X boreholes (Miller et al., 1994a, 1994b; Miller, et al., 1996a; Miller et al., Chapter 14, this volume; Miller and Sugarman, 1995; Sugarman and Miller, in press; Sugarman et al., Chapter 12, this volume) (1) identified a lowermost Miocene Kw0 sequence that is thin at Atlantic City and thick at Cape May; (2) confirmed that the Kw1 sequence consists of two distinct sequences (Kw1a and $\mathrm{Kw} 1 \mathrm{~b}$ ) at the ACGS and downdip boreholes (Fig. 2); (3) recognized an additional Kw1c sequence at Cape May; (4) subdivided the Kw2 sequence into $\mathrm{Kw} 2 \mathrm{a}$ and $\mathrm{Kw} 2 \mathrm{~b}$ at downdip boreholes and identified the Kw2c sequence at Cape May; and (5) documented a Kw-Cohansey sequence at Cape May. De Verteuil (Chapter 11, this volume) uses dinocysts to split Kw2a into Kw2a' and $\mathrm{Kw} 2 \mathrm{a}^{\prime \prime}, \mathrm{Kw} 3$ into $\mathrm{Kw} 3 \mathrm{a}$ and $\mathrm{Kw} 3 \mathrm{~b}$, and recognize one additional upper middle Miocene sequence (Ch2) and four upper Miocene sequences (Ch3-Ch6). These seven upper middle to upper Miocene sequences have been identified only at the Cape May borehole, and additional sampling is required to establish their significance.

\section{SEA LEVEL AND THE NEW JERSEY COASTAL PLAIN}

There are two principal ways to evaluate global sea-level change on passive margins. The first relies on comparison of stratigraphic records both within and between regions, with the signal in common representing eustasy (e.g., Vail et al., 1977; Haq et al., 1987). The second relies on comparison of passive margin stratigraphic records with other proxies for eustasy (e.g., $\delta^{18} \mathrm{O}$ or atoll records). We compare our results with the glacioeustatic proxy afforded by the $\delta^{18} \mathrm{O}$ record (Miller et al., 1991) and with a previous synthesis of margin records (Haq et al., 1987).

Comparison among the boreholes (Fig. 2) shows that Eocene to middle Miocene hiatuses associated with sequence boundaries correlate from site to site. Sequence boundaries are generally associated 
with hiatuses that occur throughout the coastal plain (Fig. 2). The only exceptions are sequence boundaries at the bases of O5, O6, $\mathrm{Kw} 1 \mathrm{~b}$, and Kw1c. There is no discernible hiatus associated with the base of Kw1b. The hiatuses associated with O5, O6 and Kw1c are short $(<0.5$ m.y.) and within the resolution afforded by Sr-isotopic stratigraphic resolution. Nevertheless, physical stratigraphy indicates that some time is not represented in the sediment record. Although the hiatuses correlate from site to site, the updip sections are generally less complete than the downdip section. Correlation of hiatuses among locations is consistent with a eustatic control, although other records (e.g., other margins or $\delta^{18} \mathrm{O}$ ) are needed to test for eustasy.

Deep-sea $\delta^{18} \mathrm{O}$ records provide a proxy for temperature and icevolume/sea-level (glacioeustatic) changes during the middle Eocene to Holocene "Icehouse World" (Miller et al., 1991) Glaciomarine sediments near Antarctica and deep-sea $\delta^{18} \mathrm{O}$ records indicate that large ice sheets have existed in Antarctica since the earliest Oligocene ( 33 Ma; Miller et al., 1991; Zachos et al., 1994); studies by Browning et al. (1996, Chapter 17, this volume) have extended the record of large ice sheets back until the late middle Eocene ( $45 \mathrm{Ma})$. Changes in ice volume cause changes in global seawater $\delta^{18} \mathrm{O}\left(\delta_{\mathrm{w}}\right)$ that are recorded by benthic and planktonic foraminifers, along with variations in seawater temperature and local isotopic composition. Previous studies have separated ice-volume effects from local isotopic and temperature changes by comparing benthic and low-latitude (nonupwelling) planktonic foraminiferal $\delta^{18} \mathrm{O}$ records (e.g., Shackleton and Opdyke, 1973; Miller et al., 1991; and Wright and Miller, 1992).

Miller et al. (1991) and Wright and Miller (1992) identified 12 Oligocene to Miocene benthic foraminiferal $\delta^{18} \mathrm{O}$ increases (all $>0.5$ $\%$ o). These increases culminated in $\delta^{18} \mathrm{O}$ maxima that were used to define Zones Oi1-Oi2b and Mi1-Mi7 (Fig. 3). Six of the $\delta^{18} \mathrm{O}$ increases are also recorded by tropical or subtropical planktonic foraminifers, and each represents $\sim 30-80 \mathrm{~m}$ of glacioeustatic lowering; the other six lack suitable low-latitude isotopic records but are interpreted to represent similar glacioeustatic lowerings. Further study has revealed that there are at least six to seven additional benthic foraminiferal $\delta^{18} \mathrm{O}$ increases: three to four in the Oligocene $\delta^{18} \mathrm{O}$ (Oi1a, Oi1b, Oi2b, and one possible increase "Oi2c"; Pekar and Miller, 1996; Pekar et al., Chapter 15, this volume; Fig. 3), one major middle Miocene increase (Mi3b; Miller et al., 1996d), and three smaller Miocene increases (Milaa, Milab, Mi2a; fig. 5 in Sugarman et al., Chapter 12, this volume). Insufficient planktonic $\delta^{18} \mathrm{O}$ data are available to determine the amount of glacioeustatic lowering associated with these increases.

No formal zonation of Eocene $\delta^{18} \mathrm{O}$ changes has been published. However, Browning et al. (1996; Chapter 17, this volume) synthesized available benthic and low-latitude planktonic $\delta^{18} \mathrm{O}$ records and concluded that there were three major increases in both records in the late middle Eocene that resulted from glacioeustatic lowerings of 20$40 \mathrm{~m}$. They noted the possibility of two $\delta^{18} \mathrm{O}$ increases in the early middle Eocene (Fig. 3), although $\delta^{18} \mathrm{O}$ records are still poor for this interval. There is no evidence for synchronous benthic-planktonic foraminiferal $\delta^{18} \mathrm{O}$ increases during the Paleocene to early Eocene. Browning et al. (Chapter 17, this volume) assume that this interval lacked large ice sheets, although they noted that ice-volume changes representing as much as $18 \mathrm{~m}$ of eustasy might not be detected in the $\delta^{18} \mathrm{O}$ records.

Comparison of the timing of the inflections in the $\delta^{18} \mathrm{O}$ records (= inferred glacioeustatic lowerings) with New Jersey Coastal Plain sequences and hiatuses associated with sequence boundaries (Fig. 3) shows remarkably good correspondence for the late middle Eocene to Miocene (for details see Miller et al. [Chapter 14, this volume] and Sugarman et al. [Chapter 12, this volume] for Miocene comparisons, Pekar et al. [Chapter 15, this volume] for Oligocene comparisons, and Browning et al. [Chapter 17, this volume] and Browning et al. [Chapter 18, this volume] for Eocene comparisons). In all but three cases, the inflections correlate with hiatuses between sequences. The three exceptions are for the three minor increases (Milaa, Milab, Oi2c), the timings of which are poorly constrained. For example, Sugarman et al. (Chapter 12, this volume) used Sr-isotopic data to correlate New Jersey Miocene sequences directly to the best-dated $\delta^{18} \mathrm{O}$ record at Site 747 and showed that Mi1aa and Mi1ab apparently do correlate with hiatuses. We conclude that late middle Eocene to Miocene sequence boundaries in New Jersey formed in response to glacioeustatic lowerings. This is supported by interregional correlations that show similar Miocene sequence boundaries on the New Jersey slope (Miller et al., 1996d), similar Oligocene-Miocene hiatuses in Florida (Sugarman et al., Chapter 12, this volume), and similar early Oligocene breaks in Alabama (Miller et al., 1993; see fig. 5 in Sugarman et al., Chapter 12, this volume).

The sequence boundaries in the New Jersey Coastal Plain also compare well with the sequence boundaries of Haq et al. (1987). Of the 23 Haq et al. (1987) middle Eocene to early late Miocene sequence boundaries, 12 are confirmed as hiatuses on the New Jersey Coastal Plain, six are consistent (short arrows, Fig. 3) within 0.5-m.y. resolution, and five appear to be combined into two Eocene hiatuses in New Jersey. Only three middle Eocene to early late Miocene New Jersey hiatuses lack corresponding sequence boundaries in the Haq et al. (1987) synthesis (x's on Fig. 3). Early Eocene sequence boundaries in New Jersey also agree well with Haq et al. (1987), although Paleocene correlations between the two are less clear. The poor correlation of Paleocene sequences may result from age uncertainties and limited core coverage in New Jersey, and additional coastal plain studies are needed to evaluate the ages and significance of Paleocene sequences.

Early Eocene correlations between New Jersey sequence boundaries and Haq et al. (1987) are intriguing, because they indicate a probable eustatic control. However, the apparent lack of correspondence of early Eocene sequence boundaries with the $\delta^{18} \mathrm{O}$ changes (Fig. 3) indicates that it is unlikely that glacioeustasy caused these global lowerings. There is no known mechanism for explaining large (>30 m), rapid (<1 m.y.) eustatic changes other than glacioeustasy (Pitman and Golovchenko, 1983). We conclude that mechanisms for Paleocene-early Eocene changes are poorly known.

\section{TECTONICS AND THE NEW JERSEY COASTAL PLAIN}

Owens and coauthors (Owens et al., Chapter 2, this volume and references therein) documented shifting depositional patterns on the Mid-Atlantic Coastal Plain and ascribed these differences to interbasinal tectonics. For example, progressive downwarping of the midAtlantic region to the south is indicated by a shift from an early Miocene depocenter in New Jersey to a late Miocene depocenter in Maryland (Owens et al., 1988). These differences cannot be ascribed solely to shifting sediment supply, because offshore New Jersey contains thick upper Miocene and younger deposits (Greenlee et al., 1988; Poag and Sevon, 1989; Mountain, Miller, Blum, et al., 1994). Clearly, some differential subsidence is needed to explain this and other differences between New Jersey and the region to the south (Owens et al., 1988).

Tectonic mechanisms that explain interbasinal differences in sediment distribution (e.g., differences between Maryland and New Jersey) are speculative. Owens et al. (Chapter 2, this volume) termed the progressive shifting in basin depocenters the "rolling basins" concept, but offered no causal mechanism for explaining the shifting depocenters. Brown et al. (1972) ascribed differences between basins to active tectonics (e.g., faulting of crustal blocks). Similarly Benson (1990) invoked crustal faulting to explain the patchy distribution of Oligocene deposits in Delaware and between New Jersey and Delaware. Additional drilling in the Delaware-Maryland-Virginia region 


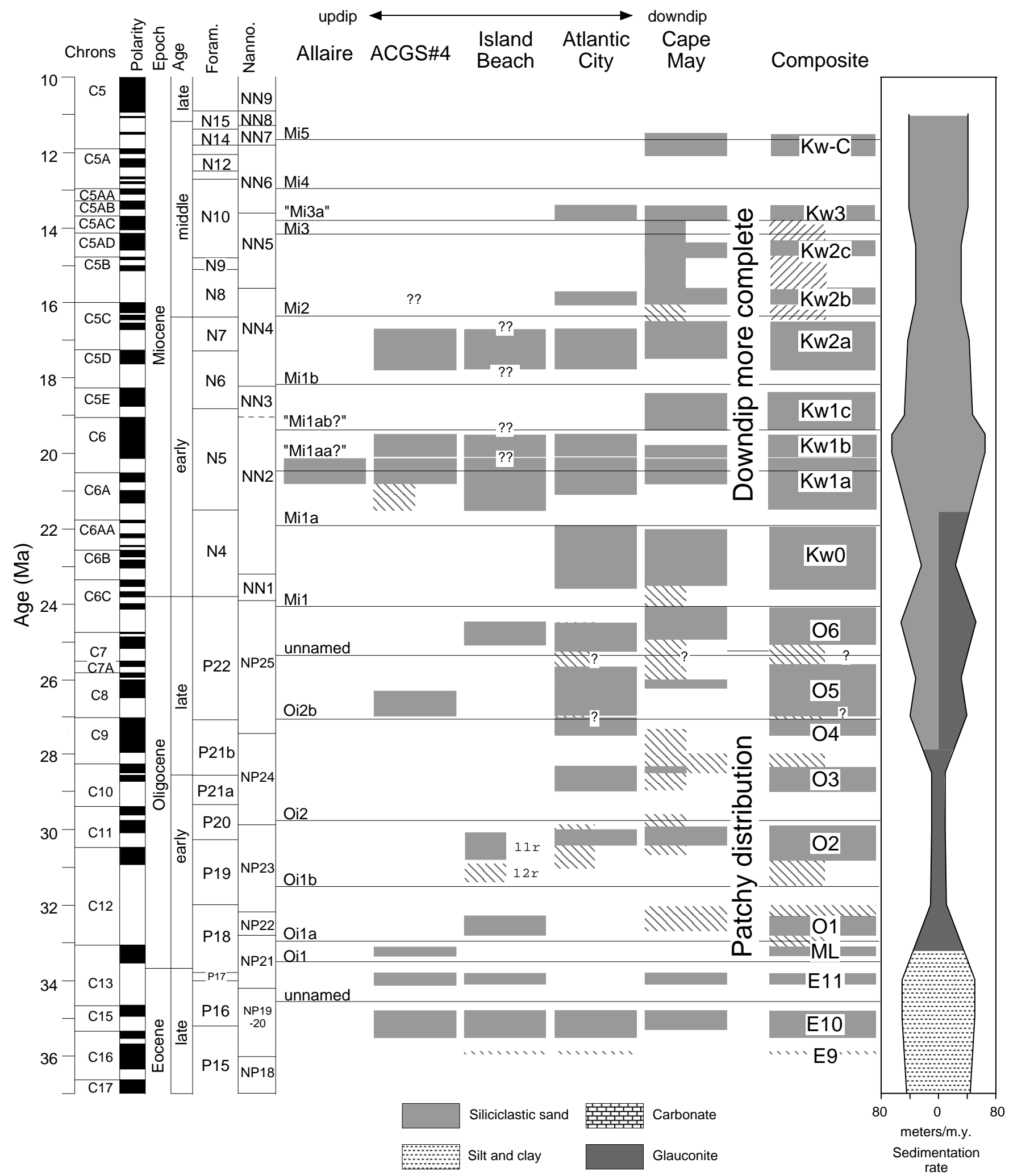

Figure 2. Distribution of the sequences found on the New Jersey Coastal Plain from (this page) the late Eocene to middle Miocene and (next page) the Paleocene to middle Eocene, shown as a function of time. Stippled pattern indicates time represented by sediments. Cross-hatched pattern indicates uncertainties in age. The time scale of Berggren et al. (1995) is used. Sedimentation rate is indicated with a "bulge" diagram, and the dominant lithologic components are indicated (see legend for component type). Oi1, Mi1, and so on are oxygen isotopic zones of Miller et al. (1991), Pekar and Miller (1996), and Miller et al. (Chapter 13 , this volume). Lines are drawn horizontally at the inflection in the $\delta^{18} \mathrm{O}$ records. 


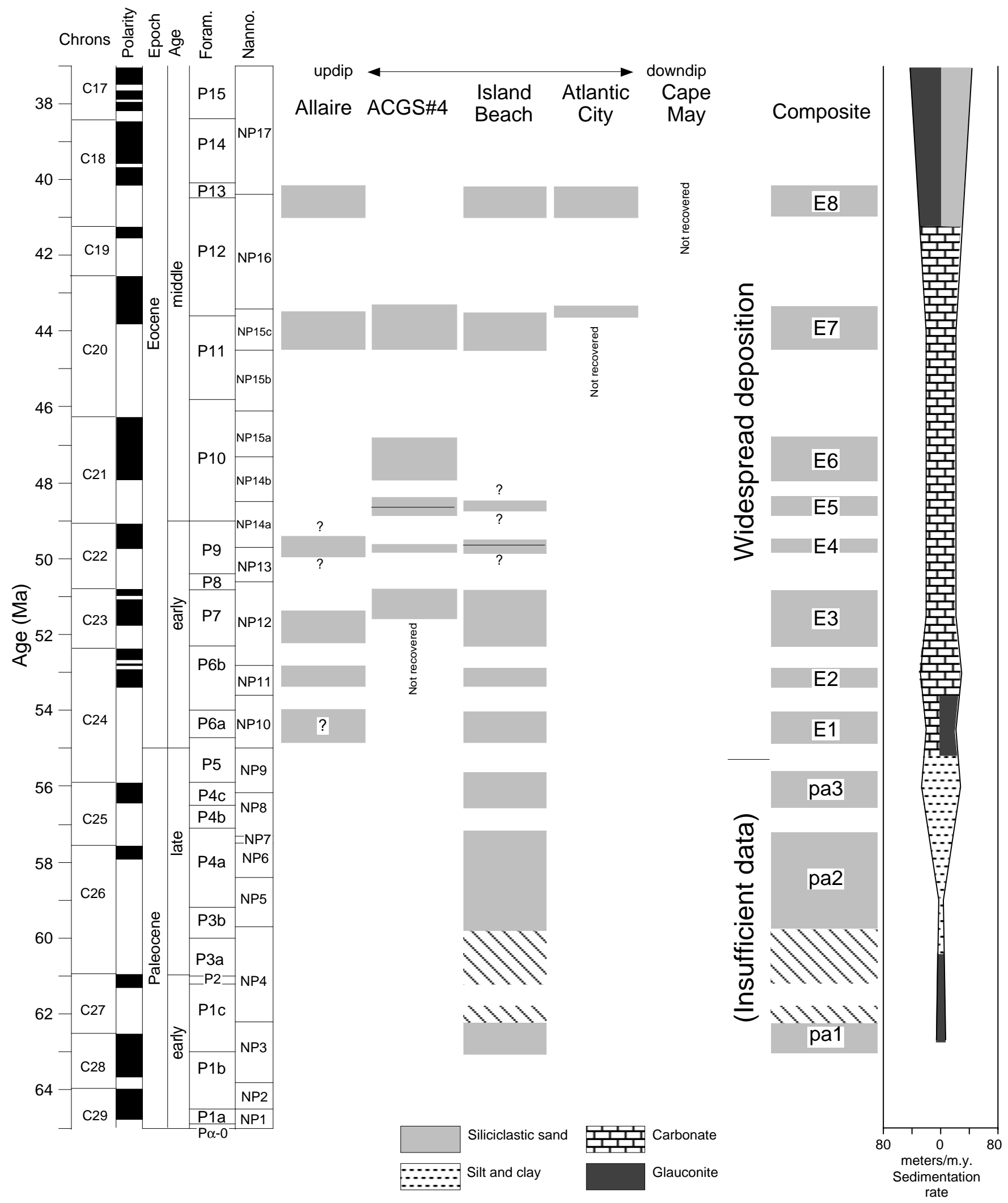

Figure 2 (continued). 


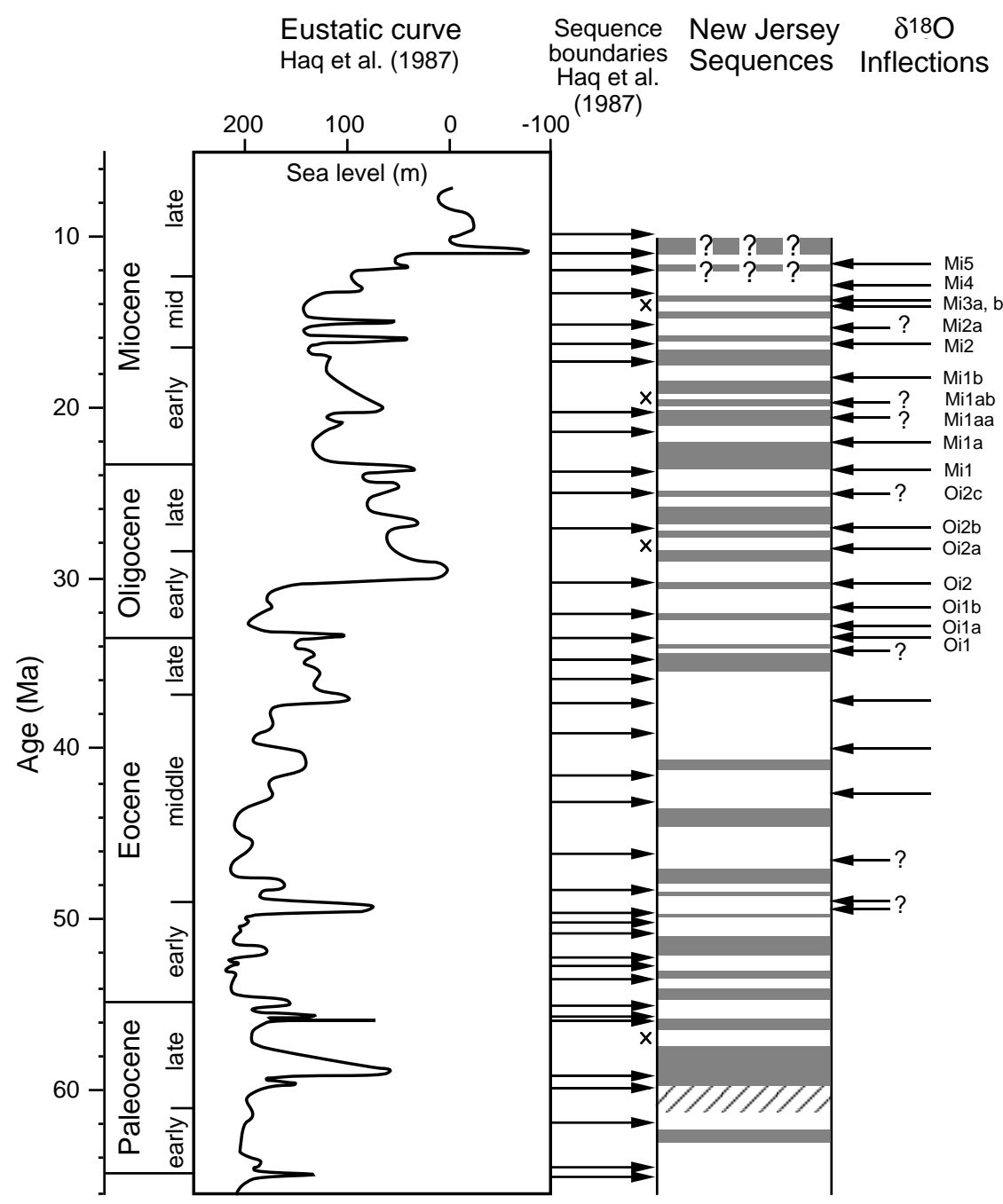

Figure 3. Distribution of the sequences found on the New Jersey Coastal Plain from the Paleocene to middle Miocene shown as a function of time and compared to the eustatic curve of Haq et al. (1987) and benthic foraminiferal $\delta^{18} \mathrm{O}$ increases. The time scale of Berggren et al. (1995) is used. The eustatic curve of Haq et al. (1987) has been replotted to the Berggren et al. (1995) time scale. Benthic foraminiferal $\delta^{18} \mathrm{O}$ inflections after Miller et al. (1991, 1996d), Wright and Miller (1992), Pekar et al. (Chapter 15, this volume), and Sugarman et al. (Chapter 12, this volume). Arrows indicate the timing of the sequence boundaries of Haq et al. (1987) and isotopic inflection. $\mathrm{x}=$ major sequence boundaries in New Jersey that are not reported by Haq et al. (1987). is needed to evaluate differences in sedimentation between these two areas and potential tectonic mechanisms.

Previous studies have mapped general sediment distribution patterns in the New Jersey Coastal Plain (Owens et al., 1995a, 1995b; Sugarman et al. 1993); differences within New Jersey may reflect interbasinal (i.e., between the Raritan and Salisbury Embayments; fig. 1 in Owens et al., Chapter 2, this volume) or intrabasinal differences (i.e., assuming that this region behaved as one crustal block). In New Jersey, Eocene basins were the most extensive areally and represent the deepest water paleoenvironments, whereas Oligocene basins were more restricted (Owens et al., Chapter 2, this volume; Fig. 2). Mapping shows that early Miocene basins in New Jersey were more extensive both updip and along strike to the north, whereas subsequent Miocene basins were more areally restricted and less influenced by marine deposition (Sugarman et al., 1993).

The Leg 150X boreholes, together with results from two previous boreholes (ACGS\#4 and Allaire), provide samples along both dip and strike (Fig. 1). The advantage of our borehole coverage is that it provides a relatively complete view of updip (e.g., Allaire) through downdip sites (e.g., Cape May), while providing a sufficient strike view to evaluate basin migration, changes in sediment source, and local erosion.

The Eocene pattern of deposition in the New Jersey Coastal Plain is simple, with widely distributed sequences both along dip and along strike (Fig. 2). This reflects high relative sea level, a gently subsiding hinged margin, and deposition in deep (>100 m) water on a gently sloping carbonate ramp (Steckler et al., 1988).
The Oligocene pattern of sediment distribution is more complex and intriguing, with patchy distribution of sequences (Fig. 2). The thickest and most complete lowermost Oligocene (O1 and $\mathrm{O} 2)$ sections are updip at Island Beach, whereas the best preserved middle Oligocene sequences (O3-O5) are at Atlantic City (Fig. 2). The thickest and best preserved uppermost Oligocene to lowermost Miocene sequences (O6, Kw0) are at Cape May (Fig. 2). This patchy distribution (Fig. 2) could be attributed to local differences in subsidence or to sediment starvation, which resulted in thin sequences that are more susceptible to erosional truncation. Although sediment starvation can potentially explain the patchy distribution of lower Oligocene strata, upper Oligocene sequences, typified by relatively high sedimentation rates, still exhibit a patchy distribution (Fig. 2).

Comparison of updip and downdip sites shows a relatively simple Miocene pattern: sequences thin and pinchout updip (Fig. 2). We interpret this as reflecting a classic, gently hinged passive margin with increased subsidence downdip.

Differences between the simple Miocene and patchy Oligocene distribution patterns yield insights to tectonic mechanisms. Coastal plain accommodation is driven by regional flexural subsidence caused by sediment loading and thermal subsidence offshore (Watts, 1981). Increased sediment supply can also cause an increase in local subsidence and accommodation because of loading effects (see also Pazzaglia and Gardner, 1994). Differential subsidence on the order of tens of meters can result from changes in sediment input; areas closest to the source experience crustal loading (both Airy and flexural) and excess accommodation. As the areas of sediment input shift 
through autocyclical processes, the localized depocenters migrate. This can result in patchy preservation, especially if sediment input is very localized, as appears to have been the case in the Oligocene.

Differential subsidence caused by switching of sediment supply can explain localized differences in Oligocene deposition. Isopach maps (fig. 13 in Pekar et al., Chapter 15, this volume) show that early Oligocene sediment supply was highest near Island Beach. By the middle Oligocene, the depocenter shifted to just south of Atlantic City, resulting in preservation of Sequences O3 to O5 at Atlantic City, which are poorly represented or absent downdip at Cape May. By the latest Oligocene to early Miocene (O6 and Kw0 time), the depocenter was closer to Cape May. These shifting loci of the thickest, most rapidly accumulating sediments resulted in excess accommodation in the early Oligocene at Island Beach, in the middle Oligocene at Atlantic City, and in the latest Oligocene to early Miocene at Cape May. This progressive migration of basins to the south is similar to the rolling basins documented for the Miocene of this region (Owens et al., 1988).

In the early Miocene ( 21 Ma; Kwla time), the depocenter shifted seaward of the Leg 150X sites (e.g., see also Greenlee et al., 1992, Poag and Ward, 1993), causing increased flexural subsidence throughout the coastal plain and more widespread early Miocene deposition. Early Miocene sedimentation rates increased in the New Jersey Coastal Plain as the main loci of deltaic deposition prograded seaward of this region (Greenlee et al., 1988), causing increased flexural subsidence throughout the coastal plain. Backstripping results (correcting for the effects of compaction, Airy loading, thermal subsidence, and long-term sea-level change) confirm an interval of increased accommodation at all three Leg 150X sites between 21 and $18 \mathrm{Ma}$, with excess subsidence continuing at Atlantic City and Cape May until 12 Ma (Miller et al., 1996b). By the late middle Miocene, deltas prograded to a position $\sim 125-\mathrm{km}$ seaward of the coastal plain (i.e., beneath the modern outer shelf), and their loading and flexural effects were minimal on the New Jersey Coastal Plain. This, together with a long-term lowering of sea level, reduced accommodation by the late Miocene, resulting in non-marine deposition or hiatuses in the New Jersey Coastal Plain (Pazzaglia and Gardner, 1994)

Based on our comparisons of deposition within New Jersey, we suggest that the fine-scale tectonic evolution of deposition in the coastal plain is intricately tied to sediment supply caused by flexural and loading effects. Although more active tectonics may have played a role in interbasinal deposition, we lack the core coverage to evaluate such a mechanism in the mid-Atlantic region.

\section{SEDIMENTATION AND THE NEW JERSEY COASTAL PLAIN}

Cenozoic deposits sampled by Leg $150 \mathrm{X}$ are typified by three dominant components: pelagic (carbonate), in situ (glauconite), and siliciclastic (sand and silt-clay; Fig. 4). Changes in the dominance of these components reflect changes in regional/global climate, oceanography, and changes in hinterland sediment supply.

Early to middle Paleocene deposition in the New Jersey Coastal Plain was characterized by glauconite sands and silts deposited at low rates $(<5 \mathrm{~m} / \mathrm{m}$.y.). During the late Paleocene (Biochron P4c-P5), there was a shift to thicker, more rapidly deposited deltaic sediments at Island Beach (Fig. 2; Liu et al., Chapter 19, this volume). Paleocene strata are poorly represented beneath the modern shelf (Poag, 1987; Olsson and Wise, 1987a), slope (Poag, Watts, et al., 1987), and rise (Tucholke and Mountain, 1986). The paucity of Paleocene strata offshore has been attributed to erosion by (1) surface currents on the shelf (Olsson and Wise, 1987a), analogous to the modern Gulf Stream which erodes the shelf south of Cape Hatteras, and (2) deep geostrophic currents on the rise (Tucholke and Mountain, 1986), analogous to the modern Western Boundary Undercurrent that erodes the rise and lower slope. Still, a thick $(\sim 200 \mathrm{~m})$ Paleocene clayey limestone recovered on the uppermost continental rise (Site 605; 2197 m present depth; Saint-Marc, 1987) documents that carbonate deposition occurred on the outer part of this margin. This reflects the generally warm regional and global climate that continued into the Eocene.

The early to middle Eocene on the New Jersey Margin was strongly influenced by pelagic carbonate deposition and warm paleoclimates. On the slope (Sites 612, 902, 903, and 904; Fig. 1), Eocene strata consist primarily of pelagic nannofossil chalks, with very little terrigenous influence; biogenic silica (or its diagenetic alteration product, porcellanite) is an important component (Poag, Watts, et al., 1987). The dominance of pelagic carbonate on the slope is attributable to a warm, productive ocean conducive to carbonate production and preservation and low siliciclastic input. In addition, the gentle ramp morphology of the Eocene New Jersey Margin (Steckler et al., 1988) allowed the influence of oceanic waters to extend inland, whereas the modern sharp shelf break restricts oceanic influence to the slope. Onshore, lower to middle Eocene strata consist of marls (carbonate silty clays) and porcellanitic marls deposited at moderate sedimentation rates ( $20 \mathrm{~m} / \mathrm{m}$.y.) Carbonate contents were only moderate (5\%-35\%) during the early Eocene (Browning et al., Chapter 17 , this volume). Carbonate content peaked during the early middle Eocene $(25 \%-60 \%)$. This peak in carbonate could be attributed either to a decrease in terrigenous clay dilution (unlikely given that sedimentation rates did not change) or other components (e.g., biogenic silica), or to a peak in surface carbonate productivity. We favor the latter, although accumulation rate data are needed to confirm a change in carbonate productivity. High amounts of biogenic silica or porcellanite during the early to middle Eocene also indicate high surface ocean productivity. The peak in pelagic carbonate and inferred carbonate productivity is not associated with either peak warming or peak water depth, both of which occurred in the early Eocene. The peak in carbonate productivity on the shelf could be attributed to a shift in the locus of deposition from the deep sea to the shelf as carbonate production apparently fell in the early middle Eocene in the deep Atlantic basin (Shackleton et al., 1984).

By the late middle Eocene, carbonate production declined to values $<5 \%$ in the study area (Fig. 5), and deposition on the shelf switched to dominantly siliciclastic components. The decrease in carbonate is mirrored by increasing $\delta^{18} \mathrm{O}$ values in deep-sea sites (Fig. 5). Offshore, carbonate production continued on the slope and rise through the late Eocene (Poag and Sevon, 1989; Miller, et al., 1996c). However, by the earliest Oligocene, deposition on the slope also switched from carbonates to siliciclastics, in concert with global $\delta^{18} \mathrm{O}$ increase (Miller, et al., 1996c).

Both of the "siliciclastic switches," onshore in the late middle Eocene and offshore in the earliest Oligocene, were associated with global cooling recorded by benthic foraminiferal $\delta^{18} \mathrm{O}$ increases (Fig. 5). Pollen studies of the ACGS\#4 borehole (Fig. 1) show that a major regional cooling event occurred in the earliest Oligocene (Owens et al., 1988); pollen data are needed for the late middle Eocene sections to confirm that the onshore siliciclastic switch is associated with a regional cooling event at this time. We suggest that regional climate dramatically changed on the East Coast of the United States in the late middle Eocene and earliest Oligocene in response to global climate changes that accompanied the growth of an Antarctic ice sheet. Cooler surface-water temperatures may have inhibited carbonate production, particularly on the wide ramp of the continental shelf.

Early late Eocene sedimentation in this region apparently was disrupted by the impact of a bolide (Poag et al., 1992, 1994; Poag and Aubry, 1995). An apparently correlative layer consisting of a mixture of reworked middle Eocene and late Eocene fossils occurs in the Leg 150X boreholes (Miller et al., 1994a, 1994b), where it comprises Sequence E9 (Browning et al., Chapter 18, this volume). Although this sequence was deposited sometime during Chron C16n1 and C15r 


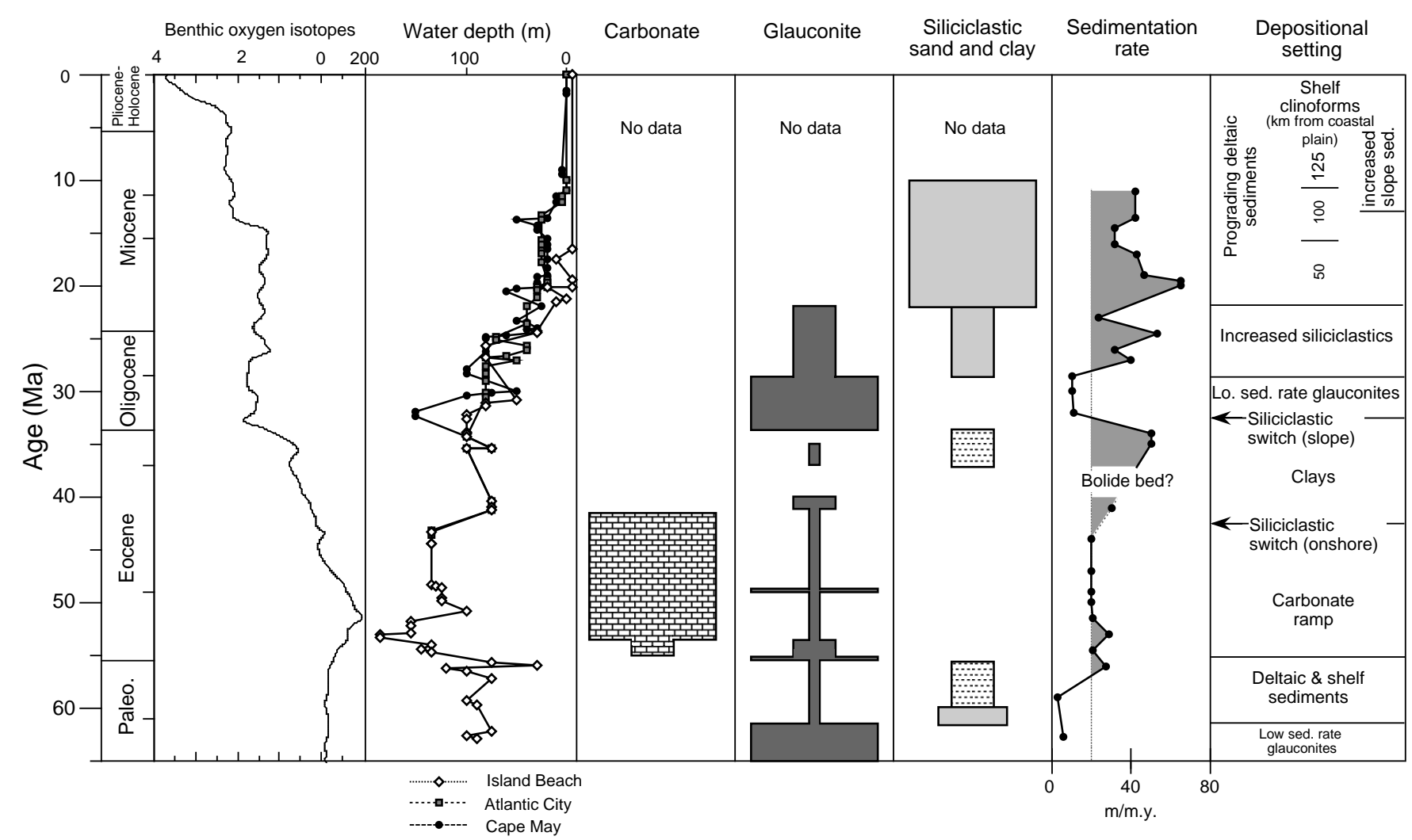

Figure 4. Composite diagram showing changes in water depth, major sediment components, sedimentation (sed.) rates, and general depositional setting of the New Jersey Coastal Plain. Changes in depositional setting include generalizations for the coastal plain (this study), distance offshore of Neogene clinoforms derived from figure 4 in Miller and Mountain (1994), and changes in slope sedimentation (Mountain, Miller, Blum, et al., 1994). The time scale is from Berggren et al. (1995). See Figure 2 for key to patterns.

(35.6-34.9 Ma; Browning et al., Chapter 18, this volume), it is possible that deposition was virtually instantaneous.

After the impact, late Eocene sedimentation in the New Jersey Coastal Plain was marked by siliciclastic clays that were rapidly deposited (>40 m/m.y.; Sequences E10 and E11; Fig. 2). Offshore, carbonate deposition still continued on the shelf (Poag, 1985) and slope (Poag, Watts, et al., 1987; Miller et al., 1996c). The high rates of clay sedimentation onshore are somewhat surprising, given the generally low amount of Eocene siliciclastic input into this region (Poag and Sevon, 1989).

The early to middle Oligocene was characterized by slow $(<20$ $\mathrm{m} / \mathrm{m} . \mathrm{y}$.), glauconite-rich sedimentation onshore. The entire margin was sediment starved throughout this interval, explaining the poor representation of strata of this age both onshore, on the slope, and in the deep basin (the "cryptic lower Oligocene"; Miller et al., 1996c). Glauconite is found not only in situ in the Transgressive Systems Tracts of onshore sequences, but also as reworked detritus in the Highstand Systems Tracts (Pekar et al., Chapter 15, this volume). The major source for terrigenous input to the Oligocene coastal plain is inferred to have been the erosion of glauconite-rich Upper Cretaceous to Eocene outcrops. On the slope, silty clays with low carbonate contents were slowly deposited during the Oligocene, with much of the lower Oligocene missing in the Leg 150 drill sites (Mountain, Miller, Blum, et al., 1994).

Sedimentation rates increased onshore to $\sim 40 \mathrm{~m} / \mathrm{m}$.y. during the late Oligocene ( 27-25 Ma; Fig. 2), and medium-coarse quartz sand appeared as an important constituent. This increase in siliciclastics clearly marks the beginning of increased sediment input from the hinterland. This change was not instantaneous: glauconite was still an important detrital mineral in earliest Miocene sequence Kw0. How- ever, by $21 \mathrm{Ma}$, deltaic sedimentation swamped glauconite deposition, and sedimentation rates reached their Cenozoic maximum of over $40 \mathrm{~m} / \mathrm{m}$.y. (Fig. 4). This early Miocene event marks a fundamental change in depositional regime, with a change from glauconitedominated shelfal deposition to deltaic deposition. High sedimentation rates and widespread deposition in the early Miocene resulted in thick onshore sequences.

Offshore, thick (hundreds of meters) clinoforms prograded beneath what is now the New Jersey continental shelf during the Miocene (e.g., Schlee, 1981). Greenlee et al. (1992) used industry wells to date well-developed prograding lower Miocene clinoforms beneath the modern inner shelf ( $\sim 50-\mathrm{km}$ seaward of Island Beach; Fig. 4; Miller and Mountain, 1994). Based on correlation with the Haq et al. (1987) cycle chart, Greenlee et al. (1988) and Greenlee and Moore (1988) suggested that shelf clinoforms began in the mid-Oligocene. The timing of the first clinoforms is not definitely known, and they could be upper Oligocene (Sequences O5 and O6; Fig. 2) or early Miocene (Sequence Kw1a), although the increase in siliciclastics in the late Oligocene (Fig. 4) probably represents the onshore equivalent of the inception of prograding clinoforms.

By the middle Miocene, prograding clinoforms were centered beneath the modern middle shelf $(\sim 100-\mathrm{km}$ seaward of Island Beach; Fig. 4; Miller and Mountain, 1994). Onshore, sedimentation rates remained high though the middle Miocene ( $40 \mathrm{~m} / \mathrm{m}$.y.). At about 13.6 $\mathrm{Ma}$, there was a dramatic increase in progradation and channel cutting on the shelf and sedimentation rates on the slope (to $>30 \mathrm{~m} / \mathrm{m}$.y.; Mountain, Miller, Blum, et al., 1994). By the late middle Miocene ( $\sim 10 \mathrm{Ma})$, clinoforms had prograded seaward to beneath the modern outer shelf ( 125-km seaward of Island Beach; Fig. 4), canyon formation became widespread on the slope due to increased sediment 


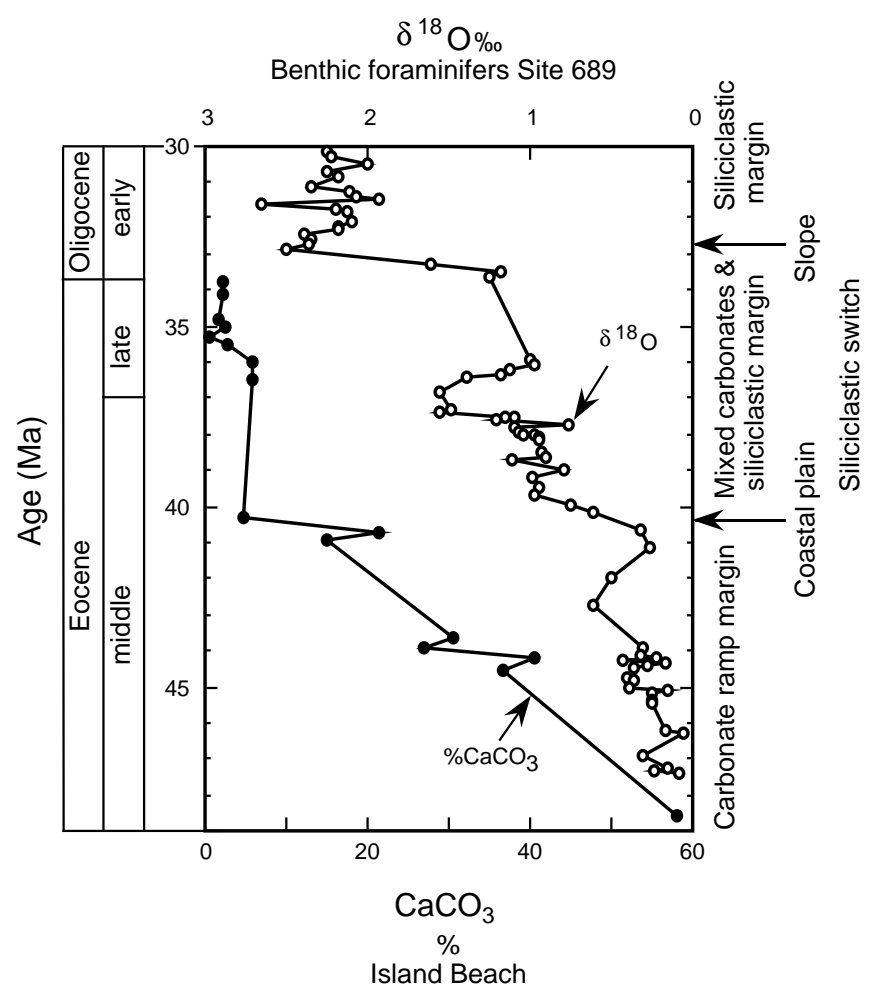

Figure 5. Comparison between percent calcium carbonate and benthic foraminiferal $\delta^{18} \mathrm{O}$ from the middle Eocene to early Oligocene in the Island Beach borehole. Note that the change from predominantly carbonate to predominantly siliciclastic sedimentation occurred in the middle Eocene ( 40 $\mathrm{Ma}$ ) on the New Jersey Coastal Plain and in the earliest Oligocene (32.7 Ma) on the continental slope. The Site 689 benthic foraminiferal $\delta^{18} \mathrm{O}$ record was measured on the specimens of Cibicidoides spp. (Kennett and Stott, 1990). Timing of the slope siliciclastic switch is from Miller et al. (1996c).

supply to this region, and slope sedimentation rates increased to $\sim 300$ m/m.y. (Miller and Mountain, 1994).

The ?Oligocene to middle Miocene development of a high-sedimentation rate, prograding regime cannot be ascribed solely to climate effects because global climate both warmed and cooled during this interval (Miller et al., 1987). Poag and Sevon (1989) and Pazzaglia (1993) ascribed Oligocene to Miocene margin transformation to changes in sediment supply linked to hinterland (central Appalachian) uplift. They emphasized the largest increase in shelf to rise sedimentation that occurred in the middle Miocene, although it is clear that the hinterland changes increased sediment supply in the New Jersey region by the late Oligocene (Fig. 4).

Lowering of long-term global sea level resulted in the shallowing of water depths in the New Jersey Coastal Plain and contributed to the offshore progradation of Miocene sequences. Kominz (1984) showed that over the long term $\left(10^{6}-10^{7} \mathrm{yr}\right.$ scale; the "first-order" fall of Vail et al., 1977), sea level fell $>50 \mathrm{~m}$ during the middle to late Eocene, $\sim 30$ $\mathrm{m}$ in the Oligocene to middle Miocene, and only $15 \mathrm{~m}$ since. Water depths decreased in the coastal plain from the early Eocene $(\sim 185-\mathrm{m}$ paleodepth), to the middle Eocene (60-135 m paleodepth), to the late Eocene-Oligocene (30- to 100-m paleodepth), to the middle Miocene $(\sim 30-\mathrm{m}$ paleodepth). The relative fall in sea level from the early Eocene to the middle Miocene resulted in a constriction of the broad ramp margin, which reduced the area available for pelagic production and caused increased input of coarse clastics resulting from base-level lowering. Although long-term sea-level lowering contributed to progradation (Miller et al., 1996c), it cannot explain the large volumes of sediment found in the Miocene-Holocene offshore vs. the relatively thin Paleogene section. Although climate cooling can explain the switch from carbonate ramp to siliciclastic margin, it also cannot explain the relatively sudden and large increase in sediment supply. We agree with Poag and Sevon (1989) that only changes in sediment supply due to hinterland tectonics can readily explain the large increase in sediment supply. Our studies indicate that the Appalachian supply began to increase in New Jersey in the late Oligocene. Further studies of provenance (Pazzaglia, 1993), sediment-mass distributions (Poag and Sevon, 1989), and erosion of the Appalachians are needed to evaluate the timing and contribution of hinterland tectonics to increased sediment supply.

\section{DISCUSSION}

The New Jersey Sea-level Transect (Legs 150 and 150X) has confirmed that the timing of sequence boundaries on the New Jersey Margin is the same as the timing of late middle Eocene to middle Miocene $\delta^{18} \mathrm{O}$ increases (Miller et al., 1996d and papers in this volume). We note that the major $(>0.5 \%$ o $) \delta^{18} \mathrm{O}$ increases (Miller et al., 1991) correspond well with sequence boundaries: Oi1 with the base of O1, Oi2 with O3, Oi2a with O4, Oi2b with O5, Mi1 with $\mathrm{Kw0}$, Mila with Kw1a, Mi1b with Kw2a, Mi2 with Kw2b, Mi3 with Kw3, and $\mathrm{Mi} 4$ with $\mathrm{Kw}$-Cohansey. Other sequence boundaries $(\mathrm{O} 6, \mathrm{Kw} 1 \mathrm{~b}$, $\mathrm{Kw} 1 \mathrm{c}, \mathrm{Kw} 2 \mathrm{c})$ appear to correlate with minor $\left(<0.5 \%\right.$ ) $\delta^{18} \mathrm{O}$ increases. However, de Verteuil (Chapter 11, this volume) notes additional sequences (splitting Kw2a and Kw3) and thus finds a less compelling correspondence between $\delta^{18} \mathrm{O}$ and sequence boundaries. De Verteuil (Chapter 11, this volume) further notes that many of the unconformities recognized in the New Jersey Coastal Plain are associated with short ( $<0.5$ m.y.) hiatuses and are thus below the temporal resolution of Sr-isotopic stratigraphy and biostratigraphy. Although de Verteuil favors a glacioeustatic cause, he notes that it is not possible to avoid an "event for every occasion" argument-that correlations between two records may be serendipitous and do not necessarily indicate causal relationships (Miall, 1991).

Using this argument, Miall (1991) claimed that stratigraphic resolution may not be sufficient to document precise correlation and causal links between sequences and the Haq et al. (1987) global synthesis. In contrast, Miller et al. (1996d) argued that it was not necessary to demonstrate that every event correlates with better than 0.5m.y. resolution. Our approach has been to anchor key stratigraphic levels to a precise chronology. We show a similar number and timing of events in the New Jersey stratigraphic, global $\delta^{18} \mathrm{O}$, and Haq et al. (1987) eustatic records, indicating that unconformities (sequence boundaries) correlate with glacioeustatic lowerings. For example, we can demonstrate that the base of Kw0 correlates with an offshore sequence boundary, and that both of these correlate precisely with the Mi1 $\delta^{18} \mathrm{O}$ increase (Miller et al., 1996d).

Miall's (1991) "event for every occasion" argument raises the issue of the scale of the events being compared. Our initial comparisons between margin stratigraphy showed that the 1- to 2-m.y.scale sequence boundaries correlate with similar events in the $\delta^{18} \mathrm{O}$ record. These 1- to 2-m.y.-scale events in the $\delta^{18} \mathrm{O}$ record reflect composites of many Milankovitch-scale $\left(10^{4}-10^{5} \mathrm{yr}\right.$ scale) climate cycles that yield long-term increases (Zachos et al., 1994). Continued study of coastal plain sections may continue to detect additional, smaller scale sequences, such as some of those detected by de Verteuil (Chapter 11, this volume). At some point, it may be possible to correlate Milankovitch-scale cycles in the coastal plain record. However, for the present, we conclude that million-yearscale sequences on the New Jersey Coastal Plain correlate with similar scale events in the $\delta^{18} \mathrm{O}$ record (Fig. 3).

We thus demonstrate that $\delta^{18} \mathrm{O}$ increases correlate with sequence boundaries and infer a causal relationship between the two. Comparisons with the Exxon record show similar timing of their sequence boundaries and ours, especially considering the 1-m.y. or worse age 
resolution inherent in the Haq et al. (1987) synthesis. Thus, our studies support the identification and general ( \pm 0.5 m.y.) ages of the Haq et al. (1987) Eocene to Miocene sequence boundaries and the timing of their eustatic record. In general, our record of sequence boundaries is better dated, and uncertainties in the ages can be specified. Therefore, we suggest that the New Jersey Margin provides a more accurate record of the timing of Eocene to Miocene eustatic falls than Haq et al. (1987).

Although our record of eustatic falls is similar to that of Haq et al. (1987), our studies do not necessarily indicate that their "eustatic" record is correct, as assumed by Kerr (1996). In fact, we believe that many of the amplitudes of their eustatic falls are incorrect. Onshore drilling cannot provide estimates of the full amplitudes of sea-level changes because of erosion during lowstands (i.e., only about half of the full sea-level cycles are represented). Shelf drilling is explicitly designed to test the amplitude of Miocene sea-level changes (Miller and Mountain, 1994), although drilling on ODP Leg 174A will not begin until 1997.

Oxygen-isotopic records provide constraints on the amplitudes of late middle Eocene to Miocene glacioeustatic changes, and these indicate that the Haq et al. (1987) estimates may be too high by a factor of two. We interpret Oligocene to middle Miocene $\delta^{18} \mathrm{O}$ increases as reflecting eustatic lowerings of $\sim 30-90 \mathrm{~m}$ and late middle Eocene increases as lowerings of $20-40 \mathrm{~m}$. The major Oligocene to Miocene benthic foraminiferal $\delta^{18} \mathrm{O}$ increases defined by Miller et al. (1991) and Wright and Miller (1992) range from $0.5 \%$ o to $1.1 \%$. Although we cannot determine precisely the amount attributable to temperature vs. ice volume, Pleistocene calibrations provide a reasonable upper limit. Ascribing a maximum of $75 \%$ of the benthic foraminiferal increases to ice volume (Fairbanks, 1989) and using the Pleistocene ice-volume/sea-level calibration of $0.11 \%$ o $10 \mathrm{~m}$ (Fairbanks and Matthews, 1978) indicates that maximum amplitudes of glacioeustatic fall were $40-75 \mathrm{~m}$. Using covariance between planktonic and benthic foraminiferal $\delta^{18} \mathrm{O}$ records yields similar Oligocene-Miocene estimates $(0.4 \% o-0.8 \%$, corresponding to $36-73 \mathrm{~m}$ of lowering), although covariance may be as low as $0.3 \%$ o- $0.4 \%$ o ( $~ 30 \mathrm{~m}$ of eustatic lowering) in some intervals (e.g., the earliest Oligocene Oil increase) and as high as $1.0 \%$ ( $90 \mathrm{~m}$ of eustatic lowering) in others (e.g., the latest Oligocene Mi1 increase). Covariance in the late middle Eocene was $0.2 \% o-0.3 \%$ ( $18-27 \mathrm{~m}$ sea-level fall). This contrasts with Exxon's eustatic lowerings for the late Eocene to middle Miocene of up to $140 \mathrm{~m}$ (Haq et al. 1987).

Although we regard use of the Pleistocene ice-volume/sea-level calibration of $0.11 \% \mathrm{o} / 10 \mathrm{~m}$ and thus the isotopic estimates of sealevel amplitude as appropriate, there is one way to reconcile the isotopic and Haq et al. (1987) estimates. The maximum $\delta^{18} \mathrm{O}$ sea-level calibration is fixed by the $\delta^{18} \mathrm{O}$ of freezing ice to $0.055 \%$ o $10 \mathrm{~m}$ (Miller et al., 1987). Use of this calibration yields eustatic lowerings of 35-180 m, similar to those of Haq et al. (1987). However, Miller et al. (1987) regarded the $0.055 \%$ o/10 m calibration as an unrealistic "outer" limit. In addition, use of this calibration requires ice volumes that approach those of the last glacial maximum, and there is no place to store such large volumes of ice during the Oligocene-Miocene (i.e., prior to large northern hemisphere ice sheets; Shackleton and Opdyke, 1973).

Relative sea-level estimates derived from the New Jersey Coastal Plain record are also consistent with lower amplitudes than those estimated by Haq et al. (1987). Although the coastal plain sites do not reflect the full amplitude of eustatic change, they do record half or so of the eustatic cycles. Water-depth changes between sequences in the late middle Eocene to middle Miocene are typically 0-80 m (Fig. 4). These water-depth changes are not corrected for isostatic effects; backstripping (correcting for the effects of compaction, Airy loading, thermal subsidence, and long-term sea-level change) indicates that relative sea-level variations for the late middle Eocene to middle Miocene were less than $50 \mathrm{~m}$ (Miller et al., 1996b). Although these estimates do not include the lowstands, they still indicate substantially smaller sea-level changes than suggested by Haq et al. (1987). Although the amplitude estimates based on $\delta^{18} \mathrm{O}$ and the New Jersey Coastal Plain are admittedly tentative, we suggest that there is sufficient evidence to doubt the amplitudes of Haq et al. (1987).

\section{FUTURE WORK}

Continuous coring at Island Beach, Atlantic City, and Cape May has met the goals of Leg 150X by dating Cenozoic sequences and evaluating facies models in an updip setting. Drilling has changed the way we view the coastal plain sequences. New Jersey onshore sections were thought to represent more stratigraphic gap than record; by strategically locating the boreholes as far downdip as possible, we were able to obtain a more complete record. Information provided by these boreholes has been beneficial not only to sequence and sea-level studies, but also to hydrogeological and regional geological studies. One of the unanticipated findings of New Jersey drilling is the clear relationship between hydrogeologic units and sequences (Sugarman and Miller, 1997). The facies changes within sequences (system tracts) need to be understood to evaluate the nature of aquifers and confining units in the New Jersey Coastal Plain. Because of their hydrogeological significance, the New Jersey Geological Survey funded drilling of one additional borehole in 1996 at Bass River State Park. This borehole will (1) recover additional pieces of the middle Eocene-Holocene "Icehouse" sequence mosaic, which include economically valuable aquifers; (2) yield detailed coverage of Paleocene-Eocene sequences, filling in critical Paleocene sections; (3) provide an opportunity to core a potentially continuous Cretaceous/Tertiary boundary section; and (4) provide a continuously cored record of New Jersey Upper Cretaceous sequences that are appropriate for evaluating sea-level changes during an interval of peak global warmth, as well as aquifer and aquitard continuity and effectiveness.

Additional coastal plain drilling beyond Bass River will be necessary to address the issues of sequences and sea level, tectonics, and sediment supply discussed here. In particular, additional drilling is needed between Atlantic City and Cape May and south of Cape May (in the Delmarva Peninsula) (1) to refine and test the significance of middle Eocene to Oligocene sequences, a number of which have only been dated at one borehole, and (2) to evaluate the distribution of sequences in view of models of tectonics (faulting vs. sediment loading) discussed here. Depending on the results at Bass River, we anticipate that at least one additional updip borehole will be needed to recover and date Upper Cretaceous to Paleocene sequences, a critical interval for evaluating sea-level changes during past warm climates. In Summer 1997, ODP Leg 174A will drill the outer shelf (Sites MAT8B and MAT9B; Fig 1), focusing on upper Neogene clinoforms. Additional drilling will be needed on the inner (Sites MAT1-3) and middle shelf (Sites MAT4-7; Fig. 1) to evaluate the facies and amplitudes of sea-level changes associated with lower to middle Miocene clinoforms. Whatever drilling the future may bring, ODP Legs 150X and 150 and their predecessors, DSDP Legs 93 and 95, have demonstrated the wealth of information (with implications for global sea level, global and regional climates, models of sequence formation, and hydrogeology) that can be obtained by continuously coring transects across passive continental margins.

\section{ACKNOWLEDGMENTS}

We thank the members of the New Jersey Coastal Plain Drilling Project for fulfilling the promise of onshore drilling, G. Mountain and N. Christie-Blick for collaboration in planning the New Jersey Sea-level Transect, and W. Newell and the late J. Owens (both U.S.Geological Survey [USGS]) for support and guidance of our ef- 
forts. The USGS BERG drillers did an outstanding job in obtaining the cores. The New Jersey Geological Survey supplied materials, personnel, and logging support. Rutgers University provided space for interim core storage and core analyses, field vehicles, and materials. R.K. Olsson (Rutgers) supplied unpublished data from other onshore wells and advice on planktonic foraminiferal studies. The National Science Foundation Continental Dynamic Program (L. Johnson, Program Director) and ODP (B. Malfait, Program Director) co-funded the onshore boreholes (Leg 150X) and, along with the JOIDES Planning Committee, are to be commended for their flexibility and vision in authorizing Leg $150 \mathrm{X}$ as an ODP activity. The publications staff at ODP was supportive throughout production of this and other Leg $150 X$ volumes. S. Snyder carefully edited all of the manuscripts submitted to this volume by the Rutgers group; I thank him for serving as co-editor of this volume. Discussions with and reviews by W. Newell, W. Poag, and S. Snyder are greatly appreciated. Supported by NSF Grants EAR92-18210 and EAR94-17108. This is LDEO contribution 5688 .

\section{REFERENCES}

Benson, R.N., 1990. Geologic and hydrologic studies of the Oligocene-Pleistocene section near Lewes, Delaware. Delaware Geol. Surv. Rep.,48:134.

Berggren, W.A., Kent, D.V., Swisher, C.C., III, and Aubry, M.-P., 1995. A revised Cenozoic geochronology and chronostratigraphy. In Berggren, W.A., Kent, D.V., Aubry, M.-P., and Hardenbol, J. (Eds.), Geochronology, Time Scales and Global Stratigraphic Correlation. Spec. Publ.Soc. Econ. Paleontol. Mineral., 54:129-212.

Brown, P.M., Miller, J.A., and Swain, F.M., 1972. Structural and stratigraphic framework, and spatial distribution of permeability of the Atlantic Coastal Plain, North Carolina to New York. Geol. Surv. Prof. Pap. U.S., 796:1-79.

Browning, J.V., Miller, K.G., and Pak, D.K., 1996. Global implications of lower to middle Eocene sequence boundaries on the New Jersey Coastal Plain-The Icehouse cometh. Geology, 24:639-642.

Christensen, B.A., Miller, K.G., and Olsson, R.K., 1995. Eocene-Oligocene benthic foraminiferal biofacies and depositional sequence at the ACGS\#4 borehole, New Jersey Coastal Plain. Palaios, 10:103-132.

Enright, R., 1969. The stratigraphy, micropaleontology, and paleoenvironmental analysis of the Eocene sediments of the New Jersey coastal plain [Ph.D. dissert.]. Rutgers University, New Brunswick, NJ.

Fairbanks, R.G., 1989. A 17,000-year glacio-eustatic sea level record: influence of glacial melting rates on the Younger Dryas event and deep-ocean circulation. Nature, 342:637-642.

Fairbanks, R.G., and Matthews, R.K., 1978. The marine oxygen isotope record in Pleistocene coral, Barbados, West Indies. Quat. Res., 10:181196.

Greenlee, S.M., Devlin, W.J., Miller, K.G., Mountain, G.S., and Flemings, P.B., 1992. Integrated sequence stratigraphy of Neogene deposits, New Jersey continental shelf and slope: comparison with the Exxon model. Geol. Soc. Am. Bull., 104:1403-1411.

Greenlee, S.M., and Moore, T.C., 1988. Recognition and interpretation of depositional sequences and calculation of sea level changes from stratigraphic data-offshore New Jersey and Alabama Tertiary. In Wilgus, C.K., Posamentier, H., Ross, C.A., and Kendall, C.G.St.C. (Eds.), SeaLevel Changes: An Integrated Approach. Spec. Publ.-Soc. Econ. Paleontol. Mineral., 42:329-353.

Greenlee, S.M., Schroeder, F.W., and Vail, P.R., 1988. Seismic stratigraphic and geohistory analysis of Tertiary strata from the continental shelf off New Jersey: calculation of eustatic fluctuations from stratigraphic data. In Sheridan, R.E., and Grow, J.A. (Eds.), The Atlantic Continental Margin. Geol. Soc. Am., Geol. North Am. Ser., 437-444.

Haq, B.U., Hardenbol, J., and Vail, P.R., 1987. Chronology of fluctuating sea levels since the Triassic. Science, 235:1156-1167.

Kennett, J.P., and Stott, L.D., 1990. Proteus and Proto-oceanus: ancestral Paleogene oceans as revealed from Antarctic stable isotopic results: ODP Leg 113. In Barker, P.F., Kennett, J.P., et al., Proc. ODP, Sci. Results, 113: College Station, TX (Ocean Drilling Program), 865-880.

Kerr, R.A., 1996. Ancient sea-level swings confirmed. Science, 272:10971098.
Kominz, M.A., 1984. Oceanic ridge volumes and sea-level change-an error analysis. In Schlee, J.S. (Ed.), Interregional Unconformities and Hydrocarbon Accumulation. AAPG Mem., 36:37-58.

Miall, A.D., 1991. Stratigraphic sequences and their chronostratigraphic correlation. J. Sediment. Petrol., 61:497-505.

Miller, K.G., et al., 1996a. Proc. ODP, Init. Repts., 150X (Suppl.): College Station, TX (Ocean Drilling Program).

Miller, K.G., Browning, J.V., Kominz, M.A., and Steckler, M., 1996b. Sealevel vs. tectonic controls on passive margin sedimentation: Results from the New Jersey Coastal Plain Drilling Project. Geol. Soc. Am. Abstr. Progr., A-62.

Miller, K.G., Browning, J.V., Liu, C., Sugarman, P., Kent, D.V., Van Fossen, M., Queen, D., Goss, M., Gwynn, D., Mullikin, L., Feigenson, M.D., Aubry, M.-P., and Burckle, L.D., 1994a. Atlantic City site report. In Miller, K.G., et al., Proc. ODP, Init. Repts., 150X: College Station, TX (Ocean Drilling Program), 35-55.

Miller, K.G., Fairbanks, R.G., and Mountain, G.S., 1987. Tertiary oxygen isotope synthesis, sea-level history, and continental margin erosion. Paleoceanography, 2:1-19.

Miller, K.G., Kent, D.V., Brower, A.N., Bybell, L.M., Feigenson, M.D., Olsson, R.K., and Poore, R.Z., 1990. Eocene-Oligocene sea-level changes on the New Jersey coastal plain linked to the deep-sea record. Geol. Soc. Am. Bull., 102:331-339.

Miller, K.G., Liu, C., and Feigenson, M.D., 1996c. Oligocene to middle Miocene Sr-isotopic stratigraphy of the New Jersey continental slope. In Mountain, G.S., Miller, K.G., Blum, P., Poag, C.W., and Twichell, D.C. (Eds.), Proc. ODP, Sci. Results, 150: College Station, TX (Ocean Drilling Program), 97-114.

Miller, K.G., and Mountain, G.S., 1994. Global sea-level change and the New Jersey margin. In Mountain, G.S., Miller, K.G., Blum, P., et al., Proc. ODP, Init. Repts., 150: College Station, TX (Ocean Drilling Program), 11-20.

Miller, K.G., Mountain, G.S., Blum, P., Gartner, S., Alm Per, G., Aubry, M.P., Burckle, L.H., Guerin, G., Katz, M.E., Christensen, B.A., Compton, J., Damuth, J.E., Deconinck, J.F., de Verteuil, L., Fulthorpe, C.S., Hesselbo, S.P., Hoppie, B.W., Kotake, N., Lorenzo, J.M., McCracken, S., McHugh, C.M., Quayle, W.C., Saito, Y., Snyder, S.W., ten Kate, W.G., Urbat, M., Van Fossen, M.C., Vecsei, A., Sugarman, P.J., Mullikin, L., Pekar, S., Browning, J.V., Liu, C., Feigenson, M.D., Goss, M., Gwynn, D., Queen, D.G., Powars, D.S., Heibel, T.D., and Bukry, D., 1996d. Drilling and dating New Jersey Oligocene-Miocene sequences: ice volume, global sea level, and Exxon records. Science, 271:1092-1095.

Miller, K.G., and Sugarman, P.J., 1995. Correlating Miocene sequences in onshore New Jersey boreholes (ODP Leg $150 \mathrm{X}$ ) with global $\delta^{18} \mathrm{O}$ and Maryland outcrops. Geology, 23:747-750.

Miller, K.G., Sugarman, P., Van Fossen, M., Liu, C., Browning, J.V., Queen, D., Aubry, M.-P., Burckle, L.D., Goss, M., and Bukry, D., 1994b. Island Beach site report. In Miller, K.G., et al., Proc. ODP, Init. Repts., 150X: College Station, TX (Ocean Drilling Program), 5-33.

Miller, K.G., Thompson, P.R., and Kent, D.V., 1993. Integrated late EoceneOligocene stratigraphy of the Alabama coastal plain: correlation of hiatuses and stratal surfaces to glacioeustatic lowerings. Paleoceanography, $8: 313-331$

Miller, K.G., Wright, J.D., and Fairbanks, R.G., 1991. Unlocking the Ice House: Oligocene-Miocene oxygen isotopes, eustasy, and margin erosion. J. Geophys. Res., 96:6829-6848.

Mountain, G.S., Miller, K.G., Blum, P., et al., 1994. Proc. ODP, Init. Repts., 150: College Station, TX (Ocean Drilling Program).

Olsson, R.K., 1991. Cretaceous to Eocene sea-level fluctuations on the New Jersey margin. Sediment. Geol., 70:195-208.

Olsson, R.K., Miller, K.G., and Ungrady, T.E., 1980. Late Oligocene transgression of middle Atlantic coastal plain. Geology, 8:549-554.

Olsson, R.K., and Wise, S.W., 1987a. Upper Maestrichtian to middle Eocene stratigraphy of the New Jersey slope and coastal plain. In van Hinte, J.E., Wise, S.W., Jr., et al., Init. Repts. DSDP, 93 (Pt. 2): Washington (U.S. Govt. Printing Office), 1343-1365.

1987b. Upper Paleocene to middle Eocene depositional sequences and hiatuses in the New Jersey Atlantic Margin. In Ross, C., and Haman, D. (Eds.), Timing and Depositional History of Eustatic Sequences: Constraints on Seismic Stratigraphy. Spec. Publ. Cushman Found. Foraminiferal Res., 24:99-112.

Owens, J.P., 1970. Post-Triassic tectonic movements in the central and southern Appalachians as recorded by sediments of the Atlantic coastal plain. 
In Fisher, G.W., Pettijohn, F.J., and Reed, J.C., Jr. (Eds.), Studies of Appalachian Geology: Central and Southern: New York (Interscience), 417427.

1983. The northwestern Atlantic Ocean margin. In Moullade, M. and Nairn, A.E.M. (Eds.), The Phanerozoic Geology of the World, II: The Mesozoic: New York (Elsevier), 33-60.

Owens, J.P., Bybell, L.M., Paulachok, G., Ager, T.A., Gonzalez, V.M., and Sugarman, P.J., 1988. Stratigraphy of the Tertiary sediments in a 945foot-deep core hole near Mays Landing in the southeastern New Jersey Coastal Plain. Geol. Surv. Prof. Pap. U.S., 1484.

Owens, J.P., and Gohn, G.S., 1985. Depositional history of the Cretaceous series in the U.S. coastal plain: stratigraphy, paleoenvironments, and tectonic controls of sedimentation. In Poag, C.W. (Ed.), Geologic Evolution of the United States Atlantic Margin: New York (Van Nostrand Reinhold), 25-86.

Owens, J.P., Minard, J.P., and Sohl, N.F., 1968. Cretaceous deltas in the northern New Jersey coastal plain, Trip B. Guidebook to Field Excursions, 40th Ann. Meeting: Flushing, NY (New York State Geol. Assoc.), $33-48$.

Owens, J.P., Minard, J.P., Sohl, N.F., and Mello, J.F., 1970. Stratigraphy of the outcroppping post-Magothy Upper Cretaceous formations in southern New Jersey and northern Delmarva Peninsula, Delaware and Maryland. Geol. Surv. Prof. Pap. U.S., 674.

Owens, J.P., Sohl, N.F., and Minard, J.P., 1977. A Field Guide to Cretaceous and Lower Tertiary Beds of the Raritan and Salisbury Embayments, New Jersey, Delaware, and Maryland: Washington, D.C. (AAPG-Soc. Econ. Paleontol. Mineral.).

Owens, J.P., Sugarman, P.J., Sohl, N.F., and Orndorff, R.C., 1995a. Geologic map of New Jersey: Southern Sheet. Open-File Rep.-U.S. Geol. Surv., 95-254.

Owens, J.P., Sugarman, P.J., Sohl, N.F., Parker, R., Houghton, H.H., Volkert, R.V., Drake, A.A., and Orndorff, R.C., 1995b. Geologic map of New Jersey: Central Sheet. Open-File Rep.-U.S. Geol. Surv., 95-253.

Pazzaglia, F.J., 1993. Stratigraphy, petrography, and correlation of late Cenozoic middle Atlantic Coastal Plain deposits: implications for late-stage passive-margin geologic evolution. Geol. Soc. Am. Bull., 105:16171634.

Pazzaglia, F.J., and Gardner, T.W., 1994. Late Cenozoic flexural deformation of the middle U. S. Atlantic passive margin. J. Geophys. Res., 99:1214312157.

Pekar, S.F., and Miller, K.G., 1996. New Jersey Oligocene "Icehouse" sequences (ODP Leg 150X) correlated with global $\delta^{18} \mathrm{O}$ and Exxon eustatic records. Geology, 24:567-570.

Pitman, W.C., III, and Golovchenko, X., 1983. The effect of sea level change on the shelf edge and slope of passive margins. Spec. Publ.-Soc. Econ. Paleontol. Mineral., 33:41-58.

Poag, C.W., 1987. The New Jersey transect: stratigraphic framework and depositional history of a sediment-rich passive margin. In Poag, C.W., Watts, A.B., et al., Init. Repts. DSDP, 95: Washington (U.S. Govt. Printing Office), 763-817.

1985. Depositional history and stratigraphic reference section for central Baltimore Canyon trough. In Poag, C.W. (Ed.), Geologic Evolution of the United States Atlantic Margin: New York (Van Nostrand Reinhold), 217-263.

Poag, C.W., and Aubry, M.-P., 1995. Upper Eocene impactites of the U.S. East Coast: depositional origins, biostratigraphic framework, and correlation. Palaios, 10:16-43.

Poag, C.W., Powars, D.S., Poppe, L.J., and Mixon, R.B., 1994. Meteroid mayhem in Ole Virginny: source of the North American tektite strewn field. Geology, 22:691-694.

Poag, C.W., Powars, D.S., Poppe, L.J., Mixon, R.B., Edwards, L.E., Folger, D.W., and Bruce, S., 1992. Deep Sea Drilling Project Site 612 bolide event: new evidence of a late Eocene impact-wave deposit and a possible impact site, U.S. east coast. Geology, 20:771-774.

Poag, C.W., and Sevon, W.D., 1989. A record of Appalachian denudation in postrift Mesozoic and Cenozoic sedimentary deposits of the U.S. middle Atlantic continental margin. Geomorphology, 2:119-157.
Poag, C.W., and Ward, L.W., 1993. Allostratigraphy of the U.S. middle Atlantic continental margin - characteristics, distribution, and depositional history of principal unconformity-bounded Upper Cretaceous and Cenozoic sedimentary units. Geol. Surv. Prof. Pap. U.S., 1542.

Poag, C.W., Watts, A.B., et al., 1987. Init. Repts. DSDP, 95: Washington (U.S. Govt. Printing Office).

Poore, R.Z., and Bybell, L.M., 1988. Eocene to Miocene biostratigraphy of New Jersey core ACGS \#4: implications for regional stratigraphy. Geol. Surv. Prof. Pap. U.S., 1829.

Posamentier, H.W., Jervey, M.T., and Vail, P.R., 1988. Eustatic controls on clastic deposition, I. Conceptual framework. In Wilgus, C.K., Hastings, B.S., Ross, C.A., Posamentier, H.W., Van Wagoner, J., and Kendall, C.G.St.C. (Eds.), Sea-Level Changes: An Integrated Approach. Spec. Publ.-Soc. Econ. Paleontol. Mineral., 42:109-124.

Saint-Marc, P., 1987. Biostratigraphic and paleoenvironmental study of Paleocene benthic and planktonic foraminifers, Site 605, Deep Sea Drilling Project Leg 93. In van Hinte, J.E., Wise, S.W., Jr., et al., Init. Repts. DSDP, 93: Washington (U.S. Govt. Printing Office), 539-547.

Schlee, J.S., 1981. Seismic stratigraphy of Baltimore Canyon Trough. AAPG Bull., 65:26-53.

Shackleton, N.J., and Opdyke, N.D., 1973. Oxygen isotope and paleomagnetic stratigraphy of equatorial Pacific core V28-238: oxygen isotope temperatures and ice volumes on a $10^{5}$ year and $10^{6}$ year scale. Quat. Res., 3:39-55.

Shackleton, N.J., Hall, M.A., and Boersma, A., 1984. Oxygen and carbon isotope data from Leg 74 foraminifers. In Moore, T.C., Jr., Rabinowitz, P.D., et al., Init. Repts. DSDP, 74: Washington (U.S. Govt. Printing Office), 599-612.

Steckler, M.S., Watts, A.B., and Thorne, J.A., 1988. Subsidence and basin modeling at the U.S. Atlantic passive margin. In Sheridan, R.E., and Grow, J.A. (Eds.), The Geology of North America (Vol. 2): The Atlantic Continental Margin. Geol. Soc. Am., 399-416.

Sugarman, P.J., and Miller, K.G., 1997. Correlation of Miocene global sequences and hydrostratigraphic units, New Jersey coastal plain. Sediment. Geol., 108:3-18.

Sugarman, P.J., Miller, K.G., Owens, J.P., and Feigenson, M.D., 1993. Strontium-isotope and sequence stratigraphy of the Miocene Kirkwood Formation, southern New Jersey. Geol. Soc. Am. Bull., 105:423-436.

Tucholke, B.E., and Mountain, G.S., 1986. Tertiary paleoceanography of the western North Atlantic Ocean. In Vogt, P.R., and Tucholke, (Eds.). The Western North Atlantic Region, Geol. Soc. Am., Geol. of North Am. Ser., M:631-650

Vail, P.R., Mitchum, R.M., Jr., Todd, R.G., Widmier, J.M., Thompson, S., III, Sangree, J.B., Bubb, J.N., and Hatlelid, W.G., 1977. Seismic stratigraphy and global changes in sea level. In Payton, C.E. (Ed.), Seismic Stratigraphy: Applications to Hydrocarbon Exploration. AAPG Mem., 26:49221.

van Hinte, J.E., Wise, S.W., Jr., et al., 1987. Init. Repts. DSDP, 93 (Pts. 1 and 2): Washington (U.S. Govt. Printing Office).

Watts, A.B., 1981. The U.S. Atlantic continental margin: subsidence history, crustal structure and thermal evolution, In Bally, A.W., Watts, A.B., Grow, J.A., Manspeizer, W., Bernoulli, D., Schreiber, C., and Hunt, J.M. (Eds.), Geology of Passive Continental Margins, AAPG Short Course Notes, 19:2/1-2/75.

Wright, J.D., and Miller, K.G., 1992. Miocene stable isotope stratigraphy, Site 747, Kerguelen Plateau. In Wise, S.W., Jr., Schlich, R., et al., Proc. ODP, Sci. Results, 120: College Station, TX (Ocean Drilling Program), 855-866.

Zachos, J.C., Stott, L.D., and Lohmann, K.C., 1994. Evolution of early Cenozoic marine temperatures. Paleoceanography, 9:353-387.

Date of initial receipt: 30 September 1996

Date of acceptance: 20 December 1996

Ms 150XSR-326 